DOI 10.23859/2587-8344-2018-2-4-6

УДК 947.084.2

Ипполитов Георгий Михайлович

Доктор исторических наук, профессор, Поволжский государственный университет телекоммуникаций и информатики

(Самара, Россия) ippo1953@yandex.ru

Ippolitov Georgii Doctor of Historical Sciences, Professor, Povolzhsky State University of Telecommunications and Informatics

(Samara, Russia) ippo1953@yandex.ru

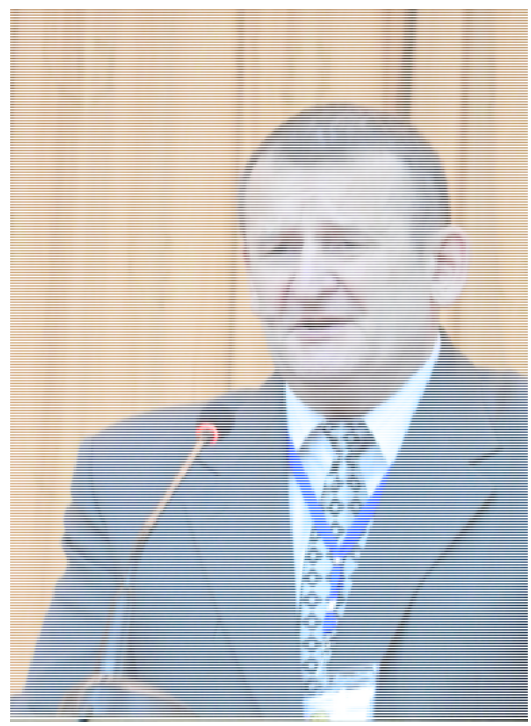

Феномен партийно-политической работы в РККА в период Гражданской войны: концептуальные основы, принципы, формы, методы (1918-1920 годы)*

\title{
The Phenomenon of Party-Political Work in the Red Army during the Civil War: Conceptual Foundations, Principles, Forms and Methods (1918-1920)
}

Аннотация. В период Гражданской войны в России (1918-1920) в Красной Армии зародилась, окрепла и успешно функционировала система партийно-политической работы. Ее создала правившая в молодой Республике Советов коммунистическая партия усилиями, главным образом, В.И. Ленина. В статье кратко раскрываются концептуальные основы, принципы, формы и методы партийно-политической работы в 1918-1920 гг. Доказывается, что они соответствовали большевистским доктринальным установкам с учетом специфики

* Для цитирования: Ипполитов Г.М. Феномен партийно-политической работы в РККА в период Гражданской войны: концептуальные основы, принципы, формы, методы (1918-1920 годы) // Historia Provinciae - Журнал региональной истории. 2018. T. 2. № 4. C. 149-177. DOI: 10.23859/2587-8344-2018-2-4-6

For citation: Ippolitov, G. "The Phenomenon of Party-Political Work in the Red Army during the Civil War: Conceptual Foundations, Principles, Forms and Methods (1918-1920)", Historia Provinciae - The Journal of Regional History, vol. 2, no. 4 (2018): 149-177, http://doi.org/ 10.23859/2587-8344-2018-2-4-6

(C) Ипполитов Г.М., 2018

(C) Ippolitov G., 2018 
исторической обстановки, складывавшейся по ходу братоубийственной российской Гражданской войны.

Ключевые слова: Гражданская война, РККА, партийно-политическая работа, В.И. Ленин, Л.Д. Троцкий, советский патриотизм, мировая революция, Советское государство.

Abstract. During the Civil War in Russia (1918-1920), the system of party-political work took its origin, strengthened and functioned successfully. It was initiated by the Communist Party, which ruled in the young Republic of Soviets, mainly by V.I. Lenin's efforts. The article briefly reveals the conceptual foundations, principles, forms and methods of party-political work in the years of 1918-20. It has been proved that they corresponded to the Bolshevik doctrinal attitudes considering the specificity of the historical situation that developed during the fratricidal struggle of the Russian Civil War.

Key words: Civil War, The Workers' and Peasants' Red Army, party-political work, Vladimir Lenin, Leon Trotsky, Soviet patriotism, the World Revolution, Soviet state

\section{Введение}

На протяжении всей истории Вооруженных сил Советского государства внутри них успешно функционировал такой уникальный исторический феномен, как партийно-политическая работа'․ Она включала в себя как идеологическую, так и организационную работу военных советов, командиров, политорганов, партийных организаций Советской армии и Военно-морского флота, являясь также и важнейшей частью руководства правящей партией Вооруженными силами. Партийно-политическая работа рассматривалась и в качестве теории и практики воспитания военнослужащих, организовывалась и проводилась как система мероприятий по реализации политики руководства Коммунистической партии Советского Союза в Советской армии и Военно-морском флоте 2 . Зародился, окреп и утвердился данный феномен в период братоубийственной российской Гражданской войны (1918-1920). Думается, в условиях, когда в начале XXI в. военная опасность для нашей Отчизны стала суровой реальностью, что признано на уровне государственной власти ${ }^{3}$, прикладывающей максимум усилий для повышения уровня боеспособности Вооруженных сил Российской Федерации, исторический опыт партийно-политической работы в Красной Армии (РККА), накопленный в хронологических рамках, указанных выше, станет вос-

${ }^{1}$ В качестве синонимов можно использовать термины «идейно-политическая работа» и «политическое воспитание».

${ }^{2}$ Епишев А.А. Актуальные вопросы партийно-политической работы в армии и на флоте. М.: Воениздат, 1984. С. 86, 112.

${ }^{3}$ Военная доктрина Российской Федерации: утв. Президентом Российской Федерации B. Путиным 26 декабря 2014 г. // Президент России [офиц. сайт]. Раздел: Документы. URL: http://www.kremlin.ru/acts/47334 (дата обращения: 21.04.2016). 
требованным в деле всемерного совершенствования военно-профессионального мастерства и морально-психологической готовности личного состава армии и флота к самоотверженному выполнению священного воинского долга по защите Родины.

Проблематика партийно-политической работы в период российской Гражданской войны нашла соответствующее отражение в советской и постсоветской историографии. Имеются здесь отдельные редкие небольшие фрагменты и сюжеты и в некоторой зарубежной исторической литературе.

Советская историография рассматриваемой проблемы развивалась в условиях методологической монополии марксизма-ленинизма, всецело приспособленного к запросам и потребностям правившей в Советском государстве коммунистической партии. Отсюда исключительно жесткие цензурные ограничения, гипертрофированная идеологизация и политизация, доминирование историко-партийных исследований, в рамках которых одним из приоритетов определили проблематику партийно-политической работы в Вооруженных силах Советского государства. Ее различные аспекты освещались в более чем 3200 монографиях, книгах, брошюрах, статьях, рецензиях, материалах научных конференций (защищенные диссертации не учитывались; подсчет, причем далеко неполный, проведен по общему и электронным каталогам Российской государственной библиотеки). Советская историография проблемы прошла за семьдесят с лишним лет путь, в котором рельефно просматривается историографическая тенденция к наращиванию усилий и темпов. Это нашло выражение в переходе от литературы агитационно-пропагандистского ${ }^{4}$ и инструктивного характера $^{5}$ к научным трудам. Сначала на уровне научных статей ${ }^{6}$, затем - специальных монографий ${ }^{7}$, защищенных диссертаций ${ }^{8}$ и, наконец, - выход на крупные обобщающие исследования ${ }^{9}$, а также на собственно историографическое осмысление анализируемой в статье проблемы ${ }^{10}$. Для всех этих работ характерно:

${ }^{4}$ Горский Г. За что воюют рабочие и крестьяне. М.: Литиздат ПУР, 1920 и др.

${ }^{5}$ Как организовать ротную ячейку: (По докладу тов. Подвойского) / Сост. Евгений Бабин. Киев: Политическое управление Народного коммисариата по военным делам Украины, 1919 и др.

${ }^{6}$ Рябичев Н. Политотдел в Гражданской войне // Революционная армия. 1921. № 1. С. 68-73; Уткин Б.П. М.В. Фрунзе о партийно-политической работе в армии и на флоте // Военно-исторический журнал. 1985. № 10. С. 52-57 и др.

${ }^{7}$ Колычев В.Г. Партийно-политическая работа в Красной Армии в годы гражданской войны 1918-1920. М.: Наука, 1979 и др.

${ }^{8}$ Владимириев В.С. Партийно-политическая работа на Южном фронте в период разгрома Деникина (окт. 1919 - янв. 1920 гг.): дис. ... канд. ист. наук. М., 1952 и др.

9 Партийно-политическая работа в Вооруженных Силах СССР (1918-1973 гг.): исторический очерк. М.: Воениздат, 1974 и др.

${ }^{10}$ Рыбников В.В. Деятельность КПСС по интернациональному воспитанию советских воинов: историографическое исследование. М.: ВПА, 1986. 
во-первых, отсутствие критического анализа недостатков, присущих партийнополитической работе, особенно в действующей армии; во-вторых, слабая архивная составляющая источниковой базы, что детерминировалось жестким режимом секретности и перманентным цензурированием; в-третьих, обилием цитат классиков-марксизма-ленинизма, лидеров правившей в Советском государстве компартии, партийных и государственных документов.

Постсоветская историография рассматриваемой проблемы характеризуется развитием сложного, до предела противоречивого процесса разработки внедрения в исследования новых теоретико-методологических подходов ${ }^{11}$. Восторжествовал плюрализм мнений в условиях относительной творческой свободы историков, аналогов которой до того времени не имелось. Российская историография, однако, впала в глубокий методологический кризис ${ }^{12}$, выход из которого состоялся лишь в начале XXI в. ${ }^{13}$ Тогда появился ряд научных статей ${ }^{14}$, специальных монографий ${ }^{15}$, а также и защищенных диссертации ${ }^{16}$, в которых анализировались многие аспекты партийно-политической работы в РККА в 1918-1920 гг.

Зарубежная историография проблемыл. Рассматриваемая проблема не проходит в ней по разряду приоритетных. Однако, к примеру, в монографии П. Кенеза (США) имеются глухие ссылки на тот факт, что партийные организации РКП(б) имели соответствующее влияние на уровень политического созна-

${ }^{11}$ Ипполитов Г.М. Российская Гражданская война в отечественной историографии второй половины 1980-х - первой половине 1990-х гг. (некоторые аспекты проблемы) // Известия Самарского научного центра Российской академии наук. 2008. Т. 10. № 1 (23). С. 204220 и др.

12 Корнеев В.В. Кризис исторической науки в России // Кентавр. 1994. № 4. С. 87-93 и др.

${ }^{13}$ Сахаров А.Н. О новых подходах к истории России // Вопросы истории. 2002. № 8. С. 3-20 и др.

${ }^{14}$ Семыкин B.A. Политорганы - организаторы агитационно-массовой работы в действующей армии (1918-1920 гг.): некоторые аспекты проблемы // Клио. 2012. № 9 (69). С. $79-$ 81; Посвятенко О.Н. Основные направления деятельности органов государственной власти и военного управления по политическому воспитанию бойцов и командиров Красной Армии в 1921-1923 гг. // Известия Самарского научного центра Российской академии наук. Т. 18. № 6. 2016. С. 55-62; Ефремов В.Я. Деятельность властных структур по укреплению морального духа вооруженных сил Советского государства (ноябрь 1917 - август 1918 г.) // Известия Самарского научного центра Российской академии наук. Т. 19. № 3. 2017. С. 70-74 и др.

15 Калашникова Е.Б. Идеологическая деятельность органов советской власти в частях действующей армии в годы Гражданской войны в России (1918-1920 гг.). Самара: СНЦ РАН, 2007 и др.

${ }^{16}$ Попова О.Н. Культурно-просветительная работа в Красной Армии: 1918-1923 гг.: автореф. дис. ... канд. ист. наук. СПб., 2009; Посвятенко О.Н. Деятельность органов государственной власти и военного управления по политическому воспитанию военнослужащих Красной армии (1918-1924): автореф. дис.... канд. ист. М., 2010 и др. 
ния личного состава красных частей и соединений ${ }^{17}$. В литературе периода холодной войны проводился тезис о «засилье» большевистской партии в Красной Армии $^{18}$, о руководстве РККА со стороны РКП(б) как «искусственном процессе» ${ }^{19}$. Ричард Пайпс кратко осветил взгляды В.И. Ленина и Л.Д. Троцкого на проблему политического восапитания бойцов Красной Армии ${ }^{20}$. Английский исследователь И. Грей признавал, что в лице В.И. Ленина Красная Армия имела подлинного и авторитетного вождя ${ }^{21}$. В монографии итальянского историка Ф. Бенвенутти «Большевики и Красная Армия» рассматривается взаимосвязь политических и военных проблем в годы Гражданской войны ${ }^{22}$. В данной связи автор разместил в тексте своего труда ряд небольших фрагментов, характеризующих проблему воинской дисциплины и ее укрепления в РККА.

\section{Основная часть}

Исторический феномен партийно-политической работы возник в Красной армии - армии нового типа, которой дотоле не имелось аналогов в историческом пространстве и во времени ${ }^{23}$. Причем, он отнюдь не представлял собой имплантированную новой властью силовым путем конструкцию, предназначенную для функционирования в войсковых структурах. Данный феномен имел стройные концептуальные основы, главным разработчиком которых стал В.И. Ленин. Именно он оставил потомкам знаменитую максиму: «Там, где наиболее заботливо проводится политработа в войсках, там тверже их дух и крепче дисциплина» ${ }^{24}$. Она стала хрестоматийной. Несмотря на современную тенденцию опровергать ленинское наследие, нельзя не признать ее правоту, особенно с учетом роли политического воспитания бойцов Красной Армии в годы Великой Отечественной войны 1941-1945 гг.

Анализ показывает, что В.И. Ленин подходил к разработке концептуальных основ партийно-политической работы в Красной Армии с сугубо утилитарных позиций. Этого требовала конкретно-историческая обстановка, складывавшаяся

${ }_{17}^{17}$ Кенез П. Красная атака, белое сопротивление. 1917-1918. М.: Центрполиграф, 2007.

${ }^{18}$ Erickson J. The Soviet High Command: A Military-Political History, 1918-1941. NewYork: St. Martin's Press, 1962.

${ }^{19}$ Mackintosh L.M. The political administration. The Red Army. Cambridge, MA/London: Harvard University Press, 1956. P. 229.

${ }^{20}$ Pipes $R$. The Formation of the Soviet Union: Communism and Nationalism, 1917-1923. Cambridge: Harvard University Press, 1997.

${ }^{21}$ Grey I. The First Fifty Years Soviet Russia, 1917-1967. London: Coward-McCann, 1967. P. 133.

${ }^{22}$ Benvenutti F. The Bolsheviks and Red Army, 1918-1922. Cambridge: Cambridge University Press, 1988.

${ }^{23}$ Молодиъьгин М.А. Красная Армия: рождение и становление. 1917-1920 гг. М.: ИРИ, 1997 и др.

${ }^{24}$ Ленин В.И. Полн. собр. соч. Т. 39. М.: Госполитиздат, 1955. С. 56. 
в 1918-1920 гг. Все концептуальные построения базировались на классовом подходе к оценке событий и явлений. Причем, на том классовом подходе, который в условиях Гражданской войны в России зачастую принимал форму зоологической классовой ненависти, культивировавшейся истерично, интенсивно и повсеместно (наглядная иллюстрация тому - ныне печально известная политика красного террора, масштабно проводившегося советской властью в период братоубийственной Гражданской войны).

В концептуальных основах партийно-политической работы в РККА имелась стержневая идея - идея всемерного повышения руководящей роли большевистской партии в экстремальных условиях Гражданской войны. Эта идея приняла форму четкой политической линии правившей в стране Российской коммунистической партии (большевиков), неукоснительно проводившейся в жизнь: насаждался перманентный и до предела жесткий партийный контроль над всеми сферами строительства Красной Армии. 25 декабря 1918 г. ЦК РКП(б) принял знаковое постановление «О политике военного ведомства». В данном документе четко зафиксирована руководящая роль РКП(б) в советском военном строительстве в целом, и в строительстве РККА в частности. Безапелляционно констатировалось: военное ведомство, точно так же, как и другие правительственные учреждения, проводят политику в сфере военного строительства и строительства РККА, только строго соблюдая общие директивы, которые им отдает РКП(б) «в лице ее Центрального Комитета». Причем, ЦК РКП(б) осуществляет здесь непосредственный контроль и проверку исполнения ${ }^{25}$. Данную политическую линию окончательно закрепил в марте 1919 г. VIII съезд РКП(б). В принятой на нем по военному вопросу резолюции отмечается, в том числе значимость для укрепления РККА работы комиссаров и коммунистических ячеек, а также и «общего партийного руководства жизнью и деятельностью армии» ${ }^{26}$.

Еще одна из ведущих идей, легших в концептуальные основы партийнополитической работы в Красной Армии, - идея необходимости целевого массированного, интенсивного и перманентного воздействия на сознание военнослужащих с целью формирования у них преданности политике советской власти, а также понимания роли РКП(б) в государстве и армии в качестве правившей партии. В.И. Ленин подчеркивал необходимость эффективного доведения до военнослужащих Красной Армии целей и задач, поставленных советской властью в условиях Гражданской войны. Что характерно: основатель Советского

25 О политике военного ведомства. Постановление Центрального комитета РКП (б). 25 декабря 1918 года // КПСС о Вооруженных Силах Советского Союза. М.: Воениздат, 1969. C. 36.

${ }^{26}$ Восьмой съезд РКП (б). Москва, 18-23 марта 1919 г.: по военному вопросу // Коммунистическая партия Советского Союза в резолюциях и решениях съездов, конференций и пленумов ЦК. М.: Институт Марксизма-Ленинизма при ЦК КПСС, 1953. Ч. 1: 1898-1925. C. $430-441$. 
государства лично дал доктринальные установки в данной связи. Их суть - учет диалектической противоречивости в решении задачи, указанной выше. С одной стороны, бойцам и командирам Красной Армии нужно было разъяснять, что война, как таковая, чужда политике советской власти, но с другой - война, которую вела Республика Советов, является справедливой войной. Ведь ее ведет пролетариат против своих жестоких вековых эксплуататоров, и он защищает свое социалистическое Отечество ${ }^{27}$. Именно здесь, согласно В.И. Ленину, кроется коренное отличие Гражданской войны от Первой мировой (империалистической, по большевистской оценке).

Анализ ленинских работ, написанных в 1918-1920 гг., показывает следующее: их автор выдвигает требование достижения сопряженности конкретного интенсивного воздействия на массовое сознание личного состава РККА с целью обеспечения уяснения им целей и задач борьбы с врагами советской власти с мобилизацией красных воинов на выполнение конкретных военных задач. Основатель Советского государства в духе ярко выраженного революционного прагматизма потребовал подчинить всю практическую деятельность решению задач, диктуемых войной ${ }^{28}$. Здесь не нужны красивые призывы. Необходимо развернуть массовую и, что особенно важно, дисциплинированную всеобъемлющую деятельность ${ }^{29}$.

В концептуальные основы партийно-политической работы в Красной Армии органически вписался такой фундаментальный постулат идеологии большевизма, как победа мировой революции. Данный фундаментальный постулат стал доминировать, начиная с первых дней строительства Красной Армии. В принятом 15 (28) января 1918 г. Декрете «Об организации Рабоче-Крестьянской Красной Армии» было прописано: «С переходом власти к трудящимся и эксплуатируемым классам возникла необходимость создания новой армии, которая явится оплотом Советской власти в настоящем, фундаментом для замены постоянной армии всенародным вооружением в ближайшем будущем и послужит поддержкой для грядущей социалистической революции в Европе» ${ }^{30}$.

Весной 1918 г. В.И. Ленин начинает осознавать, что складывающееся критическое международное положение не приведет в ближайшее время к мировой революции, она запаздывает и надо продержаться до того момента, когда она, все-таки, созреет ${ }^{31}$. Следовательно, советская власть обязана прикладывать максимум усилий для того, чтобы как можно дольше продержаться. Было не-

\footnotetext{
27 Ленин В.И. Полн. собр. соч. Т. 36. М.: Госполитиздат, 1955. С. 470.

${ }^{28}$ Ленин В.И. Полн. собр. соч. Т. 41. М.: Госполитиздат, 1955. С. 117.

${ }^{29}$ Ленин В.И. Полн. собр. соч. Т. 36. М.: Госполитиздат, 1955. С. 325.

${ }^{30}$ Декреты Советской власти. М.: Политиздат, 1957. Т. 1. С. 356.

31 Ленин В.И. Полн. собр. соч. Т. 36. М.: Госполитиздат, 1955. С. 250.
} 
возможно рассчитывать на мировую революцию, так как она вызревает намного медленнее, нежели рассчитывали большевистские функционеры в своих концептуальных построениях. Как видно, большевистский лидер проявлял определенную осторожность в оценках грядущей мировой революции. Но одновременно на протяжении 1918 г. он отмечает факты якобы приближающихся социалистических революций в различных странах (в первую очередь, в Европе) $)^{32}$. Иногда В.И. Ленин выдавал желаемое за действительное. Например, он заявил о том, что германский империализм уже рухнул ${ }^{33}$. И, все-таки, одержала победу ленинская политическая прозорливость и дальновидность. В конце 1919 г. он признал, что ошибся в своих прогнозах о быстром развертывании мировой революции ${ }^{34}$. Автор данной статьи считает, что В.И. Ленин (как бы к нему сегодня не относились) проявил в этой ситуации политическое мужество - признал ошибочность своих суждений.

Зато Л.Д. Троцкий, столь много сделавший в сфере военного строительства молодой Республики Советов, оставался (в отличие от В.И. Ленина), в плену личностной идеи мировой революции. Ее перспективность не вызывала у него никаких сомнений. Об этом он заявлял публично, к примеру, летом 1919 г., находясь на советском Южном фронте ${ }^{35}$. Именно поэтому для него Красная Армия имела двоякое предназначение: с одной стороны - защитница социалистического Отечества, а с другой - «Красная Армия III Интернационала» ${ }^{36}$. В действиях Л.Д. Троцкого явно проявлялась позиция революционного фанатизма. Так, 5 августа 1919 г. он подготовил для ЦК РКП (б) секретную записку, в которой была обоснована идея наступления подразделений Красной Армии через Среднюю Азию и Афганистан на Индию для стимулирования мировой революции в колониальных странах ${ }^{37}$. Конечно, подобные крайности здравомыслящие советские руководители не принимали, но сама идея мировой революции прочно вошла в концептуальные основы идеологической работы в РККА. Наиболее рельефно эта идея проявлялась тогда, когда дело касалось интернациональных формирований в организационной структуре Красной Армии.

В концептуальные основы партийно-политической работы в РККА органически вписалась еще одна идея - идея патриотизма, сопряженная с идеей интернационализма. Базисными в их развитии стали взгляды В.И. Ленина, суть которых сводится к следующему тезису: в капиталистическом обществе носи-

${ }^{32}$ Там же. С. 341, 398, 477-478; Т. 37. С. 64, 76, 100, 114.

33 Ленин В.И. Полн. собр. соч. Т. 37. М.: Госполитиздат, 1955. С. 191.

${ }^{34}$ Ленин В.И. Полн. собр. соч. Т. 39. М.: Госполитиздат, 1955. С. 388.

${ }^{35}$ Троцкий Л.Д. Сочинения. М.: Госиздат, 1926. Т. 17. Ч. 2. С. 191-199.

${ }^{36}$ Матюнин 3.Н. Переболевшие «левизной». В.И. Ленин и англо-американские «левые» на II конгрессе Коминтерна. Л.: Лениздат, 1990. С. 172.

${ }^{37}$ Коммунистическая оппозиция в СССР. Вермонт: Chalidze Publications, 1988. Т. 1. C. 181-184. 
телем подлинного патриотического чувства может выступать только рабочий класс и, отчасти, крестьянство (при условии, если они не являются эксплуататорами наемного труда). Эксплуататорские же слои общества В.И. Ленин однозначно лишил права на столь сложное духовное образование как чувство патриотизма $^{38}$. Такие взгляды, полагает автор данной статьи, не что иное, как догматизированные, утилитарные, сугубо классовые установки идеологии большевизма. Но это не дает весомых оснований для обвинения советской власти в антипатриотизме. Она была патриотической. Но ее патриотизм - феномен, рожденный конкретно-исторической обстановкой, который отличался по содержанию от патриотизма вообще. Дело в том, что в патриотизме советской власти нашли сопряжение две идеи: 1) идея мировой революции, преломившаяся в феномен пролетарского интернационализма); 2) идея собственно советского патриотизма ${ }^{39}$.

Вполне закономерно то, что из подобных тезисов органически вытекает положение о защите именно социалистического Отечества как сверхважнейшей задаче победившего пролетариата и всех его союзников, вне зависимости от их национального состава. Невооруженным глазом видно, что на подобный постулат оказал непосредственное влияние все тот же классовый подход к оценке событий и явлений. В то же время было нелогичным отрицать очевидное: невозможно любить свой народ, свою Родину, одновременно проявляя ненависть к другим народам и государствам. Под таким углом зрения становится ясным, почему в патриотизме советской власти нашли сопряжение идеи мировой революции (пролетарский интренационализм) и идея собственно советского патриотизма. Понятно также, почему В.И. Ленин все время подчеркивал, что в Красной Армии национальная принадлежность ее бойцов и командиров не является решающей силой для ее боеспособности ${ }^{40}$. Ведь советская власть декретировала обязанность по защите социалистического Отечества для всех граждан, вне зависимости от национальной принадлежности ${ }^{41}$. При этом Л.Д. Троцкий заявил, что из личного состава РККА следовало сформировать патриотов именно социалистической России ${ }^{42}$. Между тем, в таком советском патриотизме была вытеснена на периферию общечеловеческая сущность понятий «патриотизм» и «интернационализм», так как она не вписывалась в классические каноны одного из краеугольных камней марксизма в большевистском его измерении - классового подхода к оценке событий и явлений.

38 Ленин В.И. Полн. собр. соч. Т. 36. М.: Госполитиздат, 1955. С. 328-329.

${ }^{39}$ Там же. С. 268-269.

40 Ленинский сборник. Т. XXXVII. С. 112.

${ }^{41}$ Сборник декретов, приказов, распоряжений правительства по призывам в Красную Армию. М.: [Б.и.], 1918. С. 83.

${ }^{42}$ Троикий Л.Д. Сочинения. М.; Л.: Госиздат, 1926. Т. 17. Ч. 1. С. 153. 
Столь жесткая бескомпромиссность сопутствовала тому, чтобы концептуальные основы партийно-политической работы в Красной Армии несли в себе элементы догматизма. Но вряд ли в обстановке российской Гражданской войны от руководителей Советской России можно было ожидать других взглядов на проблему, о которой речь идет выше.

Думается, что специфика конкретно-исторической обстановки, сложившейся в исследуемый период в молодой Республике Советов, где РКП(б) имела монополию на неограниченную власть, полностью повлияла на то, чтобы в воспитании личного состава Красной Армии в духе советского патриотизма первичная роль отводилась неукоснительному соблюдению требований большевистской доктрины $^{43}$. При этом необходимо подчеркнуть, что РКП(б) смогла гармонизировать деятельность, проводившуюся в рамках партийно-политической работы в РККА по привитию красным бойцам и командирам, с одной стороны, качеств воинов-патриотов, а с другой стороны - воинов-интернационалистов. Советский патриотизм органически вписывался в решение проблемы интернациональных войсковых формирований в структуре РККА в 1918-1920 гг. Их расценивали как органическую часть Красной Армии.

И это было правильным. По сведениям Политического управления Реввоенсовета Республики, в списочном составе РККА числилось 250 тыс. иностранцев $^{44}$. Роль серьезного побудительного мотива - связать свою судьбу с Красной Армией - играла для данных людей все та же идея мировой революции. Надо отметить, что такой побудительный мотив учитывался, точнее даже эксплуатировался, в постановке дела агитации в РККА. Например, анализ политических донесений и отчетов политотдела 7 армии показывает, что в них особое внимание акцентируется на том, что в войсках интервентов возросло количество случаев братаний с красными бойцами из войск первой линии. Работники политотдела отдельно подчеркнули то, что солдаты из частей интервентов стали «переходить на нашу сторону». Более того, в отчетах политотдела 7 армии зафиксирован ряд случаев, когда в интервенционистских войсках солдаты разоружали офицеров и рядовых, если те противились переходу желающих в Красную Армию ${ }^{45}$.

В концептуальные основы партийно-политической работы в РККА легла идея жесткой централизации. Ее необходимость особо подчеркивалась в резолюции о постановке агитации и пропаганды в армии, принятой I Всероссийским съездом политработников Красной Армии в декабре 1919 г. ${ }^{46}$ Кроме того, в концептуальные основы идеологической работы заложили идею обеспечения

\footnotetext{
${ }^{43}$ Троиякий Л.Д. Моя жизнь. М.: Вагриус, 2001. С. 351.

${ }^{44}$ Российский государственный военный архив (РГВА). Ф. 9. Оп. 20. Д. 100. Л. 23.

${ }^{45}$ РГВА. Ф. 190. Оп. 2. Д. 100. Л. 98, 370.

${ }^{46}$ РГВА. Ф. 9. Оп. 11. Д. 82. Л. 31-32.
} 
единства партийно-политической работы в Красной Армии с решением задач общего просвещения красноармейцев. При этом необходимо подчеркнуть то, что В.И. Ленин проявил здесь политическую гибкость. Он дистанцировался от деятелей «Пролеткульта», которые, как известно, отнеслись с позиций нигилизма к культурному наследию прошлого. Его позиция отличалась четкостью, прагматизмом и классовым подходом к оценке событий и явлений ${ }^{47}$. В.И. Ленин, к примеру, все время подчеркивал связь просветительной деятельности с политикой. Поэтому на I Всероссийском съезде политработников Красной Армии (декабрь 1919 г.) было решено, следуя указаниям В.И. Ленина, называть воспитательную работу в Красной Армии политико-просветительной работой. Таким образом, подчеркивалась ее политическая направленность ${ }^{48}$. Съезд предложил считать неотложной задачей организацию в частях Красной Армии краткосрочных школ политической грамоты ${ }^{49}$.

Анализ источников ${ }^{50}$ и литературы ${ }^{51}$ позволяет синтезировать следующее заключение: партийно-политическая работа в РККА строилась на определенных принципах с применением своих форм и методов. К основным принципам идеологической работы в Красной Армии можно отнести следующие:

1. Научный подход, базировавшийся на теории марксизма. В основу были положены фундаментальные положения марксизма, возведенные большевист-

47 Ленин В.И. Полн. собр. соч. М.: Госполитиздат, 1955. Т. 41. С. 309, 311, 336-337, 402404, 408.

${ }^{48}$ РГВА. Ф. 9. Оп. 11. Д. 13. Л. 116.

${ }^{49}$ Там же. Л. 118.

${ }^{50}$ О принципах политико-просветительной работы в армии: резолюция I Всероссийского съезда политработников Красной армии // РГВА. Ф. 9. Оп. 11. Д. 82. Л. 19; Донесение политотдела 3 армии // РГВА. Ф. 176. Оп. 2. Д. 14; Доклад комиссара 2 Украинской дивизии И.И. Минца в политотдел Украинского фронта // РГВА. Ф. 103. Оп. 1. Д. 23. Л. 36; Инструкция для комиссара полка в действующих частях. [Б. м.], 1919; Директива всем коммунистам Южфронта. [Б. м.]. 1920; Положения и инструкции по постановке политическопросветительной работы в Красной армии. М.: Агитпросвещение , 1919 и др.

${ }^{51}$ Партийно-политическая работа в Вооруженных Силах СССР 1918-1973 гг.; исторический очерк; Культурно-просветительная работа в Вооруженных Силах СССР, 19181973 гг.: исторический очерк. М.: Воениздат, 1974; КПСС и военное строительство / под ред. А. А. Епишева. М.: Воениздат, 1982; Идеологическая работа в Вооруженных Силах СССР: историко-теоретический очерк / под ред. А. А. Епишева. М.: Воениздат, 1983; Политорганы Советских Вооруженных Сил: историко-теоретический очерк / под ред. Г. Средина. М.: Воениздат, 1984; Кольчев В.Г. Партийно-политическая работа в Красной Армии в годы гражданской войны 1918-1920. М.: Наука, 1979; Клочков В.А. Красная Армия - школа коммунистического воспитания советских воинов. 1918-1941 гг. М.: Наука, 1979; Берхин И.Б. Вопросы истории периода гражданской войны (1918-1920) в сочинениях В.И. Ленина. М.: Наука, 1981; Члиянц А.Я. В.И. Ленин - организатор партийно-политической работы в Красной Армии. Львов: Вища шк.: Изд-во при Львов. ун-те, 1984; Eпишев А. Политическим органам Советской Армии и Военно-Морского флота пятьдесят лет // Коммунист Вооруженных Сил. 1969. № 7. С. 3-24 и др. 
скими идеологами в абсолют - классовый подход к оценке событий явлений; партийность, т.е. полная идентичность идеологическим установкам и политической линии ЦК РКП(б).

2. Связь теории с практикой. Под этим понималось единство организаторской и идеологической работы, стремление обеспечить сопряженность партийно-политической работы с выполнением подразделениями Красной Армии боевых задач.

3. Строгая централизация руководства партийно-политической работой, координация усилий всех структур, проводящих рассматриваемую деятельность в Красной Армии.

4. Целеустремленность, непрерывность, оперативность, гибкость, наступательность, бескомпромиссность идеологического воздействия на военнослужащих.

5. Учет социальных и национальных особенностей личного состава частей и соединений РККА, уровня общей культуры бойцов и командиров, и, особенно, степени их грамотности.

6. Массирование сил и средств идеологического воздействия в действующей армии, особенно в войсках первой линии.

7. Применение разнообразных форм и методов.

Все эти принципы были взаимосвязаны и взаимообусловлены и вытекали из доктринальных установок марксизма, адаптированного большевистскими идеологами к нуждам и запросам политического режима советской власти. Безусловно, главная роль в разработке этих принципов принадлежит В.И. Ленину.

Формы и методы идеологического воздействия на военнослужащих Красной Армии, в отличие от принципов, отличались большей динамичностью. Представители советской власти прекрасно понимали, что нельзя научиться решать свои задачи новыми приемами сегодня, «если нам вчерашний опыт не открыл глаза на неправильность старых приемов» ${ }^{52}$.

К основным формам идейно-политической работы в Красной Армии можно отнести следующие. В организационно-партийной работе (под ней подразумеваются, прежде всего, вопросы внутрипартийной жизни, организационного строения политорганов и партийных организаций в РККА, способы, формы и методы партийной работы в соединениях и частях, вопросы повышения ее действенности и эффективности, руководства ею, сюда же входят вопросы подбора и расстановки кадров политсостава): партийные собрания, конференции, совещания, инструктажи, учеба партийного актива, обмены опытом, расстановка коммунистов в частях и соединениях, работа с кадрами политсостава и др. В идеологической работе (под ней понималось формирование у красноармейцев коммунистического мировоззрения и сознательности, преданности делу совет-

\footnotetext{
52 Ленин В.И. Полн. собр. соч. Т. 44. М.: Госполитиздат, 1955. С. 205.
} 
ской власти и РКП(б), воспитание высоких морально-психологических и боевых качеств, необходимых для достижения победы над многочисленными врагами советского политического режима; включает в себя теоретическую, агитационно-пропагандистскую и культурно-просветительную работу): политические занятия, лекции и политическое информирование красноармейцев, митинги, чтение газет и листовок, беседы, удовлетворение культурных потребностей бойцов и командиров Красной Армии и др.

К основным методам системы идеологического воздействия на военнослужащих в РККА можно отнести следующие: убеждение, упражнение, принуждение, личный пример, поощрение. Данные методы полностью совпадали и соответствовали общепринятым в военно-педагогической науке методам ${ }^{53}$, тем более, что применение их в конкретной ситуации - дело сугубо добровольное.

\section{Заключение}

Чтобы запустить механизм функционирования партийно-политической работы в РККА, В.И. Ленин (в первую очередь), а также и другие политические лидеры РКП(б) и Советского государства разработали ее концептуальные основы, принципы, формы, методы. Разрабатывая рассматриваемые концептуальные основы, В.И. Ленин стал исходить из теории марксизма, адаптируя необходимые используемые положения применительно к конкретно-исторической обстановке братоубийственной Гражданской войны в России, где тенденция к перманентной ее эскалации приобретала все более отчетливые формы: никто не хотел уступать. В рассмотренных выше концептуальных основах партийнополитической работы имеется ядро - сопряженность с военными задачами, решаемыми Красной Армией, с обязательным учетом классового подхода к оценке событий и явлений - знакового признака марксизма в большевистской его интерпретации. В рассмотренных выше концептуальных основах партийнополитической работы прослеживается и ее сущность - воздействие на умы и сердца бойцов и командиров с целью формирования у них преданности идеям большевизма, понимания политики советской власти и готовности сражаться с ее врагами до полного их уничтожения. Сражаться умело и самоотверженно, не щадя своей крови и даже жизни, что вполне соответствовало формату доктринальных установок большевизма. Отметим важное обстоятельство - в концептуальные основы идеологической работы в РККА была включена идея патриотизма, которая тесно переплелась с идеей интернационализма. В.И. Ленин создал концепцию именно своетского патриотизма, и, будучи диалектиком, соединил ее с идеей мировой революции и пролетарского интренационализма. Но лидер большевизма выхолостил общечеловеческое содержание категории «интернационализм», так как наполнил его сугубо классовым содержанием.

\footnotetext{
${ }^{53}$ См.: Военная педагогика и психология. М.: Воениздат, 1986.
} 
Относительно принципов, форм и методов партийно-политической работы в РККА, освещенных выше, представляется целесообразной такая констатация: они органически вытекают из концептуальных основ исторического феномена, анализу которого посвящена настоящая статья. Все они зиждутся, в первую очередь на жестком (а иногда даже жестоком) классовом подходе к оценкам событий и явлений. Нельзя также не заметить, что формы и методы партийнополитической работы в Красной Армии во многом обусловливались обстановкой, складывавшейся по ходу Гражданской войны. При этом, что представляется особенно важным, формы и методы партийно-политической работы в РККА отличались динамизмом и гибкостью.

В целом же тот факт, что рассмотренные выше концептуальные основы, принципы, формы и методы были разработаны, рельефно подчеркивает степень серьезности, с которой советская власть и правившая в Советском государстве компартия подходили к проблеме организации и проведения партийнополитической работы в Красной Армии. Это послужило, в конечном итоге, одним из факторов ее победы в Гражданской войне.

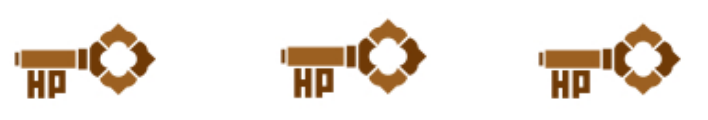

\section{Introduction}

Throughout the history of the Armed Forces of the Soviet state, a unique historical phenomenon, such as party-political work ${ }^{1}$, has successfully functioned within their structure. It included both the ideological and organizational work of military councils, commanders, political agencies, party organizations of the Soviet Army and the Navy, and was also an essential part of the leadership of the ruling party by the Armed Forces. The party-political work was also viewed as the theory and practice of military education, organized and carried out as a system of measures to implement the leadership policy of the Communist Party of the Soviet Union in the Soviet Army and the Navy ${ }^{2}$. This phenomenon was born, strengthened and gained a foothold during the fratricidal struggle of the Russian Civil War (1918-20). It seems that under the conditions when at the beginning of the $21^{\text {st }}$ century, the military danger for our Motherland has become a harsh reality, which is recognized at the level of the gov-

\footnotetext{
${ }^{1}$ The terms 'ideological and political work' and 'political education' can be used as synonyms.

${ }^{2}$ A.A. Epishev, Topical Issues of Party-Political Work in the Army and Navy (Moscow: Voenizdat, 1984), 86, 112.
} 
ernment $^{3}$, making every effort to increase the level of military capability of the Armed Forces of the Russian Federation, the historical experience of party-political work in the Red Army (Workers' and Peasants' Red Army) accumulated in the chronological framework mentioned above, will be in demand in terms of comprehensive improvement of military and professional skills and moral and psychological readiness of the personnel of both the army and the Navy regarding the selfsacrificing fulfilment of the sacred military duty to protect the homeland.

The problems of party-political work during the Russian Civil War were reflected in the Soviet and post-Soviet historiography. There are some rare, small fragments and scenes, in several foreign historical literature sources.

The Soviet historiography of the problem under consideration developed under the conditions of the methodological monopoly of Marxism-Leninism, which was entirely adapted to the needs and requirements of the Communist Party that ruled in the Soviet state. Hence, extremely strict censorship restrictions, hypertrophied ideologization and politicization, the dominance of historical party research, in which one of the priorities was to identify the issues of party-political work in the Armed Forces of the Soviet state. Its various aspects were covered in more than 3200 monographs, books, brochures, articles, review and materials of scientific conferences (defended dissertations were not considered, the estimation being far from accurate, and was carried out according to the general and electronic catalogues of the Russian State Library). Moreover, the Soviet historiography of the problem in more than seventy years made the way where the historiographic tendency towards increasing efforts and stepped-up pace is clearly visible. This found expression in the transition from propaganda ${ }^{4}$ and instructional ${ }^{5}$ literature to scientific works. First, at the level of scientific articles ${ }^{6}$, then - in special monographs ${ }^{7}$ and defended dissertations ${ }^{8}$ and finally

3 "Military doctrine of the Russian Federation: approved by President of the Russian Federation V. Putin on $26^{\text {th }}$ December 2014", in President of Russia [official web-site]. Section: Documents, http://www.kremlin.ru/acts/47334 (date of access: 04.21.2016).

${ }^{4}$ G. Gorskii, What the Workers and Peasants are Fighting for (Moscow: Litizdat PUR, 1920) and others.

${ }^{5}$ How to organize a company cell: (According to the report by Comrade Podvoiskii); Comp. Evgenii Babin. Kiev: Politicheskoe upravlenie Narodnogo kommisariata po voennym delam Ukrainy, 1919 and others.

${ }^{6}$ N. Ryabichev, "Political Department in the Civil War", Revolutionary Army, no. 1 (1921): 68-73; B.P. Utkin, "M.V. Frunze on party-political work in the army and Navy', in Military History Journal, no. 10 (1985): 52-57 and others.

${ }^{7}$ V.G. Kolychev, Party-political Work in the Red Army during the Civil War of 1918-1920 (Moscow: Nauka, 1979) and others.

${ }^{8}$ V.S. Vladimirtsev, "Party-political Work on the Southern Front during the period of Denikin's defeat (Oct. 1919-Jan. 1920)" (PhD diss. Moscow, 1952) and others. 
- via access to major generalizing research ${ }^{9}$, as well as to proper historiographical understanding of the problem ${ }^{10}$ analysed in the article. The following is characteristic for all these works: firstly, absence of a critical analysis of the shortcomings inherent in party-political work, especially in the active army; secondly, the weak archival component of the source base, which was determined by a strict secrecy regime and permanent censorship; thirdly, an abundance of quotes from the classics of MarxismLeninism, the leaders of the Communist Party that ruled the Soviet state as well as party and state documents.

The post-Soviet historiography of the problem under consideration is characterized by the development of a complex, down to the limit, contradictory process of developing an introduction to the research of new theoretical and methodological approaches ${ }^{11}$. The pluralism of opinions triumphed under the conditions of the relative creative freedom of historians, which was unparalleled prior to that time. Russian historiography, however, entered a deep methodological crisis ${ }^{12}$, the recovery from which only took place at the beginning of the $21^{\text {st }}$ century ${ }^{13}$. Then, several scientific $\operatorname{articles}^{14}$, dedicated monographs ${ }^{15}$ as well as defended dissertations appeared ${ }^{16}$, which analysed many aspects of party-political work in the Red Army in 1918-20.

Foreign historiography on the issue. The problem under consideration does not fall into the category of priority. However, for example, in P. Kenez's monograph

9 Party-political Work in the Armed Forces of the USSR (1918-1973): A historical Essay (Moscow: Voenizdat, 1974) and others.

${ }^{10}$ V.V. Rybnikov, The activities of the CPSU in the international education of Soviet soldiers: A historiographical study (Moscow: VPA, 1986).

${ }^{11}$ G.M. Ippolitov, "The Russian Civil War in the Russian historiography of the second half of the 1980s - the first half of the 1990s. (Some aspects of the problem)", in Bulletin of Samara Scientific Centre of the Russian Academy of Sciences, vol. 10, no. 1 (23) (2008): 204-20 and others.

${ }^{12}$ V. Korneev, "Crisis of historical science in Russia", in Centaur, no. 4 (1994): 87-93 and others.

${ }^{13}$ A.N. Sakharov, "On new approaches to the history of Russia", in Questions of History, no. 8 (2002): 3-20 and others

${ }^{14}$ V.A. Semykin, "Political bodies - organizers of mass campaign in the active army (19181920): Some aspects of the problem", Klio, no. 9 (69) (2012): 79-81; O.N. Posvyatenko, "The main activities of state and military authorities in the political education of fighters and commanders of the Red Army in 1921-1923", Bulletin of Samara Scientific Centre of the Russian Academy of Sciences, vol. 18, no. 6 (2016): 55-62; V.Ya. Efremov, "The activities of government structures to strengthen the morale of the armed forces of the Soviet state (November 1917 - August 1918)", in Bulletin of Samara Scientific Centre of the Russian Academy of Sciences, vol. 19, no. 3 (2017): 70-74 and others

${ }^{15}$ E.B. Kalashnikova, The Ideological Activity of the Soviet Authorities in the Units of the Active Army during the Russian Civil War (1918-1920) (Samara: SNC RAN, 2007) and others.

${ }^{16}$ O.N. Popova, "Cultural and educational work in the Red Army: 1918-1923" (PhD thesis. St Petersburg, 2009); O.N. Posvyatenko, "The activities of state bodies and military administration for the political education of the military of the Red Army (1918-1924)" (PhD thesis. Moscow, 2010) and others. 
(the USA), there are blind references to the fact that the party organizations of the $\mathrm{RCP}(\mathrm{b})$ had a corresponding influence on the level of political consciousness of the personnel of the Red units and formations ${ }^{17}$. In the literature of the Cold War period, the thesis was held on the 'dominance' of the Bolshevik Party in the Red Army ${ }^{18}$, on the leadership of the Red Army on part of the RCP(b) as an 'artificial process, ${ }^{19}$. Richard Pipes briefly covered the views of Vladimir Lenin and Leon Trotsky on the problem of political repentance of the Red Army soldiers ${ }^{20}$. The English researcher I. Gray recognized that in the person of V.I. Lenin's, the Red Army had a genuine and authoritative leader ${ }^{21}$. In the monograph of Italian historian F. Benvenutti 'The Bolsheviks and the Red Army', the relationship of political and military problems during the Civil War is considered ${ }^{22}$. In this regard, the author placed in the text of his work a few small fragments characterizing the problem of military discipline and its strengthening in the Red Army.

\section{Main body}

The historical phenomenon of party-political work arose in the Red Army - a new type of army, which until now was one-in-a-kind in the historical perspective and over time ${ }^{23}$. Moreover, it was by no means a structure implanted by the new power by force, designed to function in the military structures. This phenomenon had a coherent conceptual framework, the main developer of which was V.I. Lenin. It was he who left the descendants of the famous maxim: "Where political work is carried out most carefully in the army, their spirit is stronger, and discipline is stronger" ${ }^{24}$. It became proverbial. Despite the current trend to refute Lenin's legacy, it is impossible not to recognize its correctness, especially considering the role of the political education of the Red Army's soldiers during the Great Patriotic War of 1941-45.

The analysis shows that V.I. Lenin approached the development of the conceptual foundations of party-political work in the Red Army from purely utilitarian positions. This was required by the specific historical situation that was shaping in 1918-20. All

${ }^{17}$ P. Kenez, Red Attack, White Resistance. 1917-1918 (Moscow: Центрполиграф, 2007).

18 J. Erickson, The Soviet High Command: A Military-Political History, 1918-1941 (NewYork: St. Martin's Press, 1962).

${ }^{19}$ L.M. Mackintosh, The political administration. The Red Army (Cambridge, MA/London: Harvard University Press, 1956), 229.

${ }^{20}$ R. Pipes, The Formation of the Soviet Union: Communism and Nationalism, 1917- 1923 (Cambridge: Harvard University Press, 1997).

${ }^{21}$ I. Grey, The First Fifty Years Soviet Russia, 1917-1967 (London: Coward-McCann, 1967), 133.

${ }^{22}$ F. Benvenutti, The Bolsheviks and Red Army, 1918-1922 (Cambridge: Cambridge University Press, 1988).

${ }^{23}$ M.A. Molodtsygin, The Red Army: The birth and the Evolvement. 1917-1920 (Moscow: IRI, 1997) and others.

${ }^{24}$ V.I. Lenin, Complete Works. Vol. 39 (Moscow: Gospolitizdat, 1955), 56. 
conceptual structures were based on a class approach to the assessment of events and phenomena. Moreover, it rested upon the class approach, which during the Civil War in Russia often took the form of a 'zoological class hatred' that was cultivated hysterically, intensively and everywhere (a clear illustration of this is the now notorious policy of the Red Terror which was carried out on a large scale by the Soviet government during the period of the fratricidal Civil War).

The conceptual foundations of party-political work in the Red Army had a pivotal idea - that of enhancing the leadership role of the Bolshevik party under the extreme conditions of the Civil War. Moreover, this idea took the form of a clear political line of the Russian Communist Party (the Bolsheviks) ruling in the country, which was strictly enforced: permanent control was imposed on all spheres of formation of the Red Army. On $25^{\text {th }}$ December 1918, the Central Committee of the RCP(b) adopted a landmark resolution 'On the policy of military departments'. This document clearly stated the leading role of the RCP(b) in the Soviet force development, in general, and in the formation of the Red Army, in particular. It was categorically stated as follows: the military department, just like other government agencies, pursues a policy in the field of military construction and creation of the Red Army, only by strictly observing the general directives from the $\mathrm{RCP}(\mathrm{b})$ as "represented by its Central Committee". Moreover, the Central Committee of the RCP(b) exercises the direct control and verifies fulfilment in this respect ${ }^{25}$. This political line was finally consolidated in March 1919 by the Eighth Congress of the RCP(b). The resolution on the military issue adopted there, noted, among other things, the importance of the work of the commissars and communist cells for strengthening the Red Army, as well as the "general party leadership in the life and work of the army"26.

One more of the leading ideas that formed the conceptual foundations of partypolitical work in the Red Army was that of the need for targeted massive, intensive and permanent influence on the consciousness of soldiers to build their loyalty to the policy of Soviet power, as well as to understand the role of the RCP(b) and the army as the ruling party. Lenin emphasized the need to effectively communicate to the servicemen of the Red Army the goals and tasks set by the Soviet government during the Civil War. Characteristically: the founder of the Soviet state personally gave the doctrinal guidelines in this connection. Their essence was considering the dialectic contradiction in solving the problem indicated above. On the one hand, it was necessary to clarify to the soldiers and commanders of the Red Army that the war, as such, was

25 "On the policy of the Military Department. Resolution of the Central Committee of the RCP (b). $25^{\text {th }}$ December 1918", in The CPSU on the Armed Forces of the Soviet Union (Moscow: Voenizdat, 1969), 36.

26 "The Eighth Congress of the RCP(b). Moscow, 18-23 ${ }^{\text {rd }}$ March 1919: on the military issue", in The Communist Party of the Soviet Union in resolutions and decisions of congresses, conferences and plenums of the Central Committee (Moscow: Institut Marksizma-Leninizma pri CK KPSS, 1953. Part 1: 1898-1925), 430-41. 
alien to the policy of the Soviet government; however, on the other hand, the said war led by the Republic of Soviets was a fair one. After all, it was being led by the proletariat against its cruel centuries-old exploiters, and it was defending its socialist Fatherland $^{27}$. It was there, according to V.I. Lenin, where the fundamental difference between the Civil War and the First World War (imperialist, according to the Bolshevik assessment) was concealed.

An analysis of Lenin's works, written in 1918-20, shows the following: the author makes it necessary to achieve the inter-linking of specific intensive influence on the mass consciousness of the Red Army personnel in order to ensure that they understood the goals and objectives of the struggle against the enemies of Soviet power with the mobilization of Red 'warriors' to perform specific military tasks. The founder of the Soviet state, in the spirit of strongly pronounced revolutionary pragmatism, demanded that all practical activity be subordinated to the solution of tasks dictated by the $\operatorname{war}^{28}$. Moreover, beautiful appeals were not needed there. It was necessary to develop large-scale and, most importantly, disciplined comprehensive activities ${ }^{29}$.

The fundamental postulate of Bolshevism ideology, such as the victory of the World Revolution, organically fits into the conceptual foundations of party-political work in the Red Army. This fundamental postulate began to dominate from the first days of the creation of the latter. Adopted on $5^{\text {th }}\left(28^{\text {th }}\right)$ January 1918 , the decree 'on the creation of the Workers' and Peasants' Red Army' was written as follows: "with the transition of power to the working and exploited classes, there was a need to create a new army, which will be a stronghold of Soviet power in the present, the Foundation for the replacement of a permanent army with national weapons in the near future and will serve as support for the upcoming socialist revolution in Europe"30.

In the spring of 1918, V.I. Lenin began to realize that the emerging critical international situation would not lead to a world revolution soon; it was late, and it was necessary to hold out until the moment when it nevertheless matured ${ }^{31}$. Consequently, the Soviet government was obliged to exert maximum efforts to hold out for as long as possible. Moreover, without counting on the World Revolution, as it matured much more slowly than the Bolshevik functionaries expected in their conceptual constructions. As one can see, the Bolshevik leader showed certain caution in assessing the coming World Revolution. But at the same time, throughout 1918, he noted the facts of the allegedly approaching socialist revolutions in various countries (primarily in Europe $)^{32}$. Moreover, sometimes V.I. Lenin gave what he wished for as real. As an

\footnotetext{
${ }^{27}$ V.I. Lenin, Complete Works, vol. 36, 470.

${ }^{28}$ V.I. Lenin, Complete Works, vol. 41, 117.

${ }^{29}$ V.I. Lenin, Complete Works, vol. 36, 325.

${ }^{30}$ Decrees of the Soviet Government (Moscow: Politizdat, 1957, vol. 1), 356.

${ }^{31}$ V.I. Lenin, Complete Works, vol. 36, 250.

${ }^{32}$ V.I. Lenin, Complete Works, vol. 36, 341, 398, 477-478; Vol. 37, 64, 76, 100, 114.
} 
example, he declared that German imperialism had already collapsed ${ }^{33}$. Nevertheless, Lenin's political insight and foresight won there. At the end of 1919, he admitted that he had been mistaken in his predictions about the rapid deployment of the World Revolution $^{34}$. The author of this article believes that V.I. Lenin (no matter how he is thought of today) showed political courage in this situation - he acknowledged the fallacy of his judgments.

However, Leon Trotsky, who had done so much in the field of military construction of the young Republic of Soviets, remained (unlike V.I. Lenin), 'in captivity' of the personal idea of the World Revolution. Its prospects did not cause him any doubt. He stated this publicly, for example, in the summer of 1919, whilst on the Soviet Southern Front ${ }^{35}$. That is why for him the Red Army had a dual purpose: on the one hand, the defender of the socialist Fatherland, and on the other, the Red Army of the Third International ${ }^{36}$. The position of Leon Trotsky clearly showed the position of revolutionary fanaticism. Thus, on $5^{\text {th }}$ August 1919, he prepared a secret note for the Central Committee of the RCP(b), in which the idea of an offensive of the Red Army units through Central Asia and Afghanistan towards India was justified to stimulate the World Revolution in colonial countries ${ }^{37}$. It goes without saying, the sensible Soviet leaders did not accept such extremes, but the very idea of a World Revolution was firmly established in the conceptual foundations of the ideological work in the Red Army. Moreover, this idea manifested itself most clearly when it came to the international formations in the organizational structure of the Red Army.

One more idea organically fit into the conceptual foundations of party-political work in the Red Army: that of patriotism, coupled with the idea of internationalism. The views of V.I. Lenin were the basis in their development, and their essence can be reduced to the following thesis: in capitalist society, only the working class and partly, the peasantry can be the bearer of genuine patriotic feeling (provided they are not exploiters of hired labour). V.I. Lenin unequivocally deprived the exploiting strata of society of the right to such a complex spiritual education as a sense of patriotism $^{38}$. Such views, as the author of this article believes, are nothing but dogmatized, utilitarian, purely class attitudes of the ideology of Bolshevism. But this does not give weighty grounds for accusing the Soviet authorities of anti-patriotism. They were patriotic indeed. However, their patriotism was a phenomenon born out of a specific historical setting that differed in content from patriotism in general. The fact is that

${ }^{33}$ V.I. Lenin, Complete Works, vol. 37, 191.

${ }^{34}$ V. I. Lenin, Complete Works, vol. 39, 388.

${ }^{35}$ L.D. Trotsky, Works, vol. 17, part 2 (Moscow: Gosizdat, 1924-1927), 191-99.

${ }^{36}$ Z.N. Matyunin, Recover from 'leftism'. V.I. Lenin and the Anglo-American 'Left' at the $2^{\text {nd }}$ World Congress of the Comintern (Leningrad: Lenizdat, 1990), 172.

37 The Communist opposition in the USSR (Vermont: Chalidze Publications, 1988, vol. 1), $181-84$.

${ }^{38}$ V.I. Lenin, Complete Works, vol. 36, 328-29. 
within patriotism of the Soviet power, two ideas found a connection: 1) the idea of the World Revolution, which was transformed into the phenomenon of proletarian internationalism); and 2) the idea of Soviet patriotism itself ${ }^{39}$.

It is not without reason that from such a thesis, the provisions on protection of the socialist Fatherland as the most important task of the victorious proletariat and all its allies follow naturally. Notably, regardless of their ethnic composition. It can be seen with the naked eye that such a postulate was directly influenced by the same class approach to the assessment of events and phenomena. At the same time, it was illogical to deny the obvious: it was impossible to love one's people, one's homeland, whilst at the same time showing hatred for other countries and nations. From this point of view, it becomes clear why the ideas of the World Revolution (proletarian internationalism) and the idea of Soviet patriotism could be found in the patriotism of the Soviet government. It is also clear why V.I. Lenin emphasized repeatedly that in the Red Army, the national identity of its fighters and commanders was not the decisive force for its military capability ${ }^{40}$. After all, the Soviet government decreed the obligation to protect the socialist fatherland for all citizens, regardless of their nationality ${ }^{41}$. At the same time, Leon Trotsky declared that it was necessary to convince patriots of socialist Russia from amongst the personnel of the Red Army ${ }^{42}$. Meanwhile, in such Soviet patriotism, the universal essence of the concepts 'patriotism' and 'internationalism' was pushed to the periphery, since it did not fit into the classical canons of one of the cornerstones of Marxism in its Bolshevik dimension - the class approach to the assessment of events and phenomena.

Such a rigid uncompromising attitude accompanied the fact that the conceptual foundations of party-political work in the Red Army carried elements of dogmatism. However, under the conditions of the Russian Civil War, it was unlikely that the leaders of Soviet Russia could be expected to have other views on the problem discussed above.

It seems that the specificity of the historical situation that developed during the period under study in the young Republic of Soviets, where the RCP (b) had a monopoly on unlimited power, fully influenced the strict role in the upbringing of the Red Army personnel in the spirit of Soviet patriotism requirements of the Bolshevik doctrine $^{43}$. It should be emphasized that the RCP (b) was able to harmonize the activities carried out within the framework of the party-political work in the Red Army to instil in the Red fighters and commanders, on the one hand, the qualities of patriotic

${ }^{39}$ V.I. Lenin, Complete Works, vol. 36, 268-69.

${ }^{40}$ Lenin collection, vol. XXXVII, 112.

${ }^{41}$ Collection of decrees, orders, regulations of the government on the military conscription to the Red Army (Moscow: b./i. (sine nomine), 1918), 83.

${ }^{42}$ L.D. Trotsky, Works (Moscow; Leningrad: Gosizdat, 1926, vol. 17, part 1), 153.

${ }^{43}$ L.D. Trotsky, My Life (Moscow: Vagrius, 2001), 351. 
soldiers, and on the other hand, to do the same amongst the international soldiers. Moreover, Soviet patriotism organically fit into the solution of the problem of international military formations in the structure of the Red Army in 1918-20. They were regarded as an integral part of the Red Army.

And that came out right. According to the Political Department of the Revolutionary Military Council of the Republic, there were 250,000 foreigners enlisted in the Red Army ${ }^{44}$. Moreover, the role of a serious motive - to cast in their lot with the Red Army - was the same idea of the World Revolution for these people. It should be noted that such a motive was considered, more precisely, was exploited, to formulate the case of agitation in the Red Army. As an example, an analysis of political reports and the reports of the political department of the $7^{\text {th }}$ Army shows that they focused on the fact that the number of cases of fraternization with the Red fighters from the first line troops increased among the interventionist forces. In that connection, the workers of the political department stressed on a separate note that the soldiers from the interventionist units began to "take their side". Moreover, in the reports of the political department of the $7^{\text {th }}$ army, several cases were recorded when the soldiers in the interventionist forces disarmed the officers and privates if they opposed the transfer of those who wanted to join the Red Army ${ }^{45}$.

The idea of rigid centralization lay in the conceptual foundations of partypolitical work in the Red Army. Its necessity was distinctively emphasized in the resolution on the formulation of agitation and propaganda in the army, adopted by the First All-Russian Congress of Political Workers of the Red Army in December $1919^{46}$. In addition, the conceptual foundations of ideological work laid the idea of ensuring the unity of party-political work in the Red Army with the solution of the tasks of general education within the Red Army. At the same time, it is necessary to emphasize that V. I. Lenin showed political flexibility in this respect. He distanced himself from the leaders of Proletkult, who, as is well known, reacted from the position of nihilism to the cultural heritage of the past. His position was distinguished by clarity, pragmatism and class approach to the assessment of events and phenomena ${ }^{47}$. V.I. Lenin, for example, repeatedly emphasized the connection of educational activities with politics. Therefore, at the First All-Russian Congress of Political Workers of the Red Army (December 1919), it was decided, following the instructions of V.I. Lenin, to call the educational work in the Red Army as political-educational one. Thus, its political focus was emphasized ${ }^{48}$. The Congress proposed to consider ar-

\footnotetext{
${ }^{44}$ Rossiiskii gosudarstvennyi voennyi arkhiv (RGVA) f. 9, op. 20, d. 100, 1. 23.

${ }^{45}$ RGVA f. 190, op. 2, d. 100, 1. 98, 370.

${ }^{46}$ RGVA f. 9, op. 11, d. 82, 1. 31-32.

${ }^{47}$ V.I. Lenin, Complete Works, vol. 41, 309, 311, 336-337, 402-404, 408.

${ }^{48}$ RGVA f. 9, op. 11, d. 13, 1.116.
} 
rangement of short-term schools of political literacy in the Red Army as an urgent $\operatorname{task}^{49}$.

The analysis of sources ${ }^{50}$ and literature ${ }^{51}$ allows us to synthesize the following conclusion: the party-political work in the Red Army was based on certain principles using its forms and methods. The main principles of ideological work in the Red Army included the following: 1. The scientific approach, based on the theory of Marxism. It was based on the fundamental propositions of Marxism, erected by the Bolshevik ideologues as an absolute - a class approach to the assessment of the events of phenomena; the party spirit, that is, the complete identity of ideological attitudes and the political line of the Central Committee of the RCP (b). 2. The connection of theory with practice. This meant the unity of organizational and ideological work, the desire to ensure the connection of party-political work with the performance of combat tasks by the Red Army units. 3. Strict centralization of the leadership of party-political work, coordination of the efforts of all structures conducting the activity in question within the Red Army. 4. Purposefulness, continuity, efficiency, flexibility, offensiveness and uncompromising ideological impact on the military personnel. 5. Considering the social and national characteristics of the personnel in the units and formations of the Red Army, the level of the general culture of the soldiers and commanders, and especially their degree of literacy. 6. Concentration of forces and means of ideological influence in the active army, especially in the troops on the front line. 7. Application of various forms and methods.

${ }^{49}$ Ibid, 1. 118.

${ }^{50}$ On the principles of political and educational work in the army: "The resolution of the First All-Russian Congress of Political Workers of the Red Army", in RGVA f. 9, op. 11, d. 2.2, 1. 19; "The report of the political department of the $3^{\text {rd }}$ army", in RGVA f. 176, op. 2, 1. 14; "Report of the Commissioner of the $2^{\text {nd }}$ Ukrainian Division of I.I. Mintz in the political department of the Ukrainian front", in RGVA f. 103, op. 1, d. 23, 1. 36; Instruction for the regimental commissar in operating units ([B. m.], 1919); Directive to all the communists of the Southern Front ([B. m.] 1920); Provisions and instructions for the formulation of political and educational work in the Red Army (Moscow: Agitprosveshchenie, 1919) and others.

51 "Party-political work in the Armed Forces of the USSR in 1918-1973; historical essay", in Cultural and educational work in the Armed Forces of the USSR, 1918-1973: Historical essay (Moscow: Voenizdat, 1974); CPSU and military construction; ed. A. A. Epishev (Moscow: Voenizdat, 1982); Ideological work in the Armed Forces of the USSR: A historical and theoretical essay; ed. A. A. Epishev (Moscow: Voenizdat, 1983); Political organs of the Soviet Armed Forces: A historical and theoretical essay; ed. G. Sredin (Moscow: Voenizdat, 1984); V.G. Kolychev, Party-Political work in the Red Army during the Civil War of 1918-1920 (Moscow: Nauka, 1979); V. Klochkov. The Red Army as a School of Communist Education for Soviet soldiers. 1918-1941 (Moscow: Nauka, 1979); I.B. Berkhin, Questions of the History of the Civil War Period (19181920) in the works of V.I. Lenin (Moscow: Nauka, 1981); A.Ya. Chliyants, V.I. Lenin - organizer of party-political work in the Red Army (Lviv: Vishha shk.: Izd-vo pri L'vov. un-te, 1984); A. Epishev, "50 ${ }^{\text {th }}$ anniversary of the political organs in the Soviet Army and the Navy", in Communist Armed Forces, no. 7 (1969), 3-24 and others. 
All these principles were interrelated and interdependent and flowed from the doctrinal guidelines of Marxism, adapted by the Bolshevik ideologues to the needs and demands of the political regime of Soviet power. By all means, the main role in the development of these principles belonged to V.I. Lenin.

The forms and methods of ideological influencing the servicemen of the Red Army, in contrast to the principles, were more dynamic. Representatives of the Soviet authorities understood it was impossible to learn how to solve their problems at present armed with the new methods, "if yesterday's experience did not open our eyes of to the incorrectness of the old methods" $"$.

The main forms of ideological and political work in the Red Army included the following. In the organizational party work (it implied, first of all, the issues of innerparty life, the organizational structure of political agencies and party organizations in the Red Army, ways, forms and methods of party work in the formations and units, the issues of increasing its potential and efficacy, its management; here also referred the issues of selection and placement of political personnel): party sessions, conferences, meetings, briefings, training of party activists, experience exchanges, distribution of communists in units and formations, staff relations, etc. In the ideological work (it was understood as the formation of communist worldview and consciousness of the Red Army soldiers, devotion to the Soviet power and the RCP (b), raising their high morale, nurturing psychological and combat qualities necessary to achieve victory over the numerous enemies of the Soviet political regime included theoretical, propaganda and cultural-educational work): citizenship training, lectures and political briefing of the Red Army personnel, political meetings, reading newspapers and leaflets, conversations, meeting the cultural needs of the soldiers and commanders of the Red Army, etc.

The main methods of the system of ideological influence on the military personnel in the Red Army included the following: persuasion; exercise; compulsion; personal example; encouragement. These methods completely coincided and corresponded to the common methods adopted in the military pedagogical science in general $^{53}$, especially as their application in a specific situation was a purely voluntary matter.

\section{Conclusion}

To set the wheels on motion for the party-political work in the Red Army, V.I. Lenin (first of all), as well as other political leaders of the RCP (b) and the Soviet state, developed their conceptual foundations, principles, forms and methods. In developing the conceptual framework under consideration, V.I. Lenin began to proceed from the theory of Marxism, adapting the required provisions already in use, in rela-

\footnotetext{
${ }^{52}$ V.I. Lenin, Complete Works, vol. 44, 205.

${ }^{53}$ See: Military Pedagogy and Psychology (Moscow: Voenizdat, 1986).
} 
tion to the specific historical situation of the fratricidal struggle in the Russian Civil War, where the tendency towards permanent escalation acquired a determinate shape: no one wanted to cede. In the conceptual foundations of party-political work considered above, there was a core - its connection with the military tasks assigned to the Red Army, with the obligatory consideration of a class approach to the assessment of events and phenomena - the sign of Marxism in the Bolshevik interpretation. In the conceptual foundations of party-political work considered above, its essence can also be traced - the impact on the minds and hearts of fighters and commanders with the goal of building loyalty to the ideas of Bolshevism, understanding the policy of Soviet power and readiness to fight its enemies until they are destroyed. To fight skilfully and selflessly, not sparing their own blood and even life, which was quite consistent with the format of the Bolshevism doctrinal guidelines. We note an important fact here - the idea of patriotism was included in the conceptual foundations of the ideological work in the Red Army, which was closely intertwined with the idea of internationalism. V.I. Lenin created the conception of Soviet patriotism, and, being a dialectician, he combined it with the idea of World Revolution and proletarian internationalism. However, the leader of Bolshevism diluted the universal content of the category 'internationalism', since he filled it with purely class content.

Regarding of the principles, forms and methods of party-political work in the Red Army, as discussed above, it seems appropriate to make the following statement: they organically followed from the conceptual foundations of the historical phenomenon, to the analysis of which this article is devoted. All of them were based, first, on a hard-line (and sometimes even cruel) class approach to evaluating events and phenomena. Also, one cannot but notice that the forms and methods of party-political work in the Red Army were largely due to the situation evolving during the fratricidal Civil War. At the same time, which is particularly important, the forms and methods of party-political work in the Red Army were distinguished by dynamism and flexibility.

In general, the fact that the above-mentioned conceptual foundations, principles, forms and methods were developed clearly, underlines the degree of seriousness with which the Soviet government and the Communist Party that ruled the Soviet state approached the problem of organizing and conducting the party-political work in the Red Army. This was, ultimately, one of the factors of the victory of the Red Army in the Civil War.

\section{Список литературы}

Берхин И.Б. Вопросы истории периода гражданской войны (1918-1920) в сочинениях В.И. Ленина. М.: Наука, 1981. 368 с.

Владимириев B.C. Партийно-политическая работа на Южном фронте в период разгрома Деникина (октябрь 1919 - январь 1920 гг.): дис. ... канд. ист. наук. М.: [Б.и.], 1952. 334 с. 
Военная педагогика и психология / под ред. А.В. Барабанщикова. М.: Воениздат, 1986. $240 \mathrm{c}$.

Горский Г. За что воюют рабочие и крестьяне. М.: Литиздат ПУР, 1920. 16 с.

Епишев A. Политическим органам Советской Армии и Военно-Морского флота пятьдесят лет // Коммунист Вооруженных Сил. 1969. № 7. С. 3-24.

Епишев A.A. Актуальные вопросы партийно-политической работы в армии и на флоте. М.: Воениздат, 1984. 224 с.

Ефремов В.Я. Деятельность властных структур по укреплению морального духа вооруженных сил Советского государства (ноябрь 1917 - август 1918 г.) // Известия Самарского научного центра Российской академии наук. Т. 19. № 3. 2017. С. 70-74.

Идеологическая работа в Вооруженных Силах СССР: историко-теоретический очерк / под ред. А. А. Епишева. М.: Воениздат, 1983. 344 с.

Ипполитов Г.М. Российская Гражданская война в отечественной историографии второй половины 1980-х - первой половине 1990-х гг. (некоторые аспекты проблемы) // Известия Самарского научного центра Российской академии наук. 2008. Т. 10. № 1 (23). С. 204-220.

Как организовать ротную ячейку: (По докладу тов. Подвойского) / сост. Евгений Бабин. 2-е изд. Киев: Политическое управление Народного коммисариата по военным делам Украины, 1919. 8 с.

Калашникова Е.Б. Идеологическая деятельность органов советской власти в частях действующей армии в годы Гражданской войны в России (1918-1920 гг.). Самара: СНЦ РАН, 2007. 112 c.

Кенез П. Красная атака, белое сопротивление. 1917-1918 / пер. с англ. К.А. Никифорова. М.: ЗАО Центрполиграф, 2007. 287 с.

Клочков B.A. Красная Армия - школа коммунистического воспитания советских воинов. 1918-1941 гг. М.: Наука, 1979. 227 с.

Кольчев В.Г. Партийно-политическая работа в Красной Армии в годы гражданской войны 1918-1920. М.: Наука, 1979. 407 с.

Корнеев В. В. Кризис исторической науки в России // Кентавр. 1994. № 4. С. 87-93.

КПСС и военное строительство / под ред. А. А. Епишева. М.: Воениздат, 1982. 312 с.

Матюнин 3.Н. Переболевшие «левизной». В.И. Ленин и англо-американские «левые» на II конгрессе Коминтерна. Л.: Лениздат, 1990. 254 с.

Молодиьъгин М.А. Красная Армия: рождение и становление. 1917-1920 гг. М.: ИРИ, 1997. $234 \mathrm{c}$.

Партийно-политическая работа в Вооруженных Силах СССР (1918-1973 гг.): исторический очерк / под ред. А.А. Епишева. М.: Воениздат, 1974. 366 с.

Политорганы Советских Вооруженных Сил : историко-теоретический очерк / под ред. Г. Средина. М.: Воениздат, 1984. 432 с.

Попова О.Н. Культурно-просветительная работа в Красной Армии: 1918-1923 гг.: автореф. дис. ... канд. ист. наук. СПб.: [Б.и.], 2009. 26 с.

Посвятенко О.Н. Деятельность органов государственной власти и военного управления по политическому воспитанию военнослужащих Красной армии (1918-1924): автореф. дис. ... канд. ист. наук. М.: [Б.и.], 2010. 24 с.

Посвятенко О.Н. Основные направления деятельности органов государственной власти и военного управления по политическому воспитанию бойцов и командиров Красной Армии в 1921-1923 гг. // Известия Самарского научного центра Российской академии наук. Т. 18. № 6. 2016. С. 55-62. 
Рыбников В.В. Деятельность КПСС по интернациональному воспитанию советских воинов: историографическое исследование. М.: ВПА, 1986. 206 с.

Рябичев Н. Политотдел в Гражданской войне // Революционная армия. 1921. № 1. С. 6873.

Сахаров А.Н. О новых подходах к истории России // Вопросы истории. 2002. № 8. С. 3 20 .

Семыкин B.A. Политорганы - организаторы агитационно-массовой работы в действующей армии (1918-1920 гг.): некоторые аспекты проблемы // Клио. 2012. № 9 (69). С. 79-81.

Уткин Б.П. М. В. Фрунзе о партийно-политической работе в армии и на флоте // Военно-исторический журнал. 1985. № 10. С. 52-57.

Члияни А.Я. В.И. Ленин - организатор партийно-политической работы в Красной Армии. Львов: Вища шк.: Изд-во при Львов. ун-те, 1984. 168 с.

Benvenutti $F$. The Bolsheviks and Red Army, 1918-1922. Cambridge: Cambridge University Press, 1988. 264 p.

Erickson J. The Soviet High Command: A Military-Political History, 1918-1941. New-York: St. Martin's Press, 1962. 889 p.

Grey I. The First Fifty Years Soviet Russia, 1917-1967. London: Coward-McCann, 1967. $558 \mathrm{p}$.

Mackintosh L.M. The political administration. The Red Army. Cambridge, MA/London: Harvard University Press, 1956. 480 p.

Pipes R. The Formation of the Soviet Union: Communism and Nationalism, 1917-1923. Cambridge: Harvard University Press, 1997. 365 p.

\section{References}

Benvenutti F. The Bolsheviks and Red Army, 1918-1922. Cambridge: Cambridge University Press, 1988. 264 p.

Berkhin, I.B. Voprosy istorii perioda grazhdanskoi voiny (1918-1920) v sochineniyakh V.I. Lenina [Questions of the History of the Civil War Period (1918-1920) in the Works of V.I. Lenin]. Moscow: Nauka, 1981. 368 p. (In Russian)

Chliyants, A.Ya. V.I. Lenin - organizator partiino-politicheskoi raboty v Krasnoi Armii [V.I. Lenin - organizer of party-political work in the Red Army]. L'vov: Vishcha shk.: Izd-vo pri L'vov. un-te, 1984. 168 p. (In Russian)

Efremov, V.Ya. "Deyatel'nost' vlastnykh struktur po ukrepleniyu moral'nogo dukha vooruzhennykh sil Sovetskogo gosudarstva (noyabr' 1917 - avgust 1918 g.) [The activities of government structures to strengthen the morale of the armed forces of the Soviet state (November 1917 - August 1918)]", Izvestiya Samarskogo nauchnogo tsentra Rossiiskoi akademii nauk [Bulletin of Samara Scientific Centre of the Russian Academy of Sciences], vol. 19, no. 3 (2017): 70-74. (In Russian)

Epishev, A.A. Aktual'nye voprosy partiino-politicheskoi raboty $v$ armii $i$ na flote [Topical Issues of Party-Political Work in the Army and Navy]. Moscow: Voenizdat, 1984. 224 p. (In Russian)

Epishev, A. "Politicheskim organam Sovetskoi Armii i Voenno-Morskogo flota pyat'desyat let" $\left[50^{\text {th }}\right.$ anniversary of the political bodies of the Soviet Army and the Navy], Kommunist Vooruzhennykh Sil [Communist of the Armed Forces], vol. 7 (1969): 3-24. (In Russian)

Erickson, J. The Soviet High Command: A Military-Political History, 1918-1941. New-York: St. Martin's Press, 1962. 889 p. 
Gorskii, G. Za chto voyuyut rabochie i krest'yane [What the Workers and Peasants are Fighting for]. Moscow: Litizdat PUR, 1920. 16 p. (In Russian)

Grey, I. The First Fifty Years Soviet Russia, 1917-1967. London: Coward-McCann, 1967. $558 \mathrm{p}$.

Ideologicheskaya rabota $v$ Vooruzhennykh Silakh SSSR: istoriko-teoreticheskii ocherk [Ideological work in the Armed Forces of the USSR: A historical and theoretical essay]; edited by A.A. Epishev. Moscow: Voenizdat, 1983. 344 p. (In Russian)

Ippolitov, G.M. "Rossiiskaya Grazhdanskaya voina v otechestvennoi istoriografii vtoroi poloviny 1980-kh - pervoi polovine 1990-kh gg. (nekotorye aspekty problemy)" [The Russian Civil War in the Russian historiography of the second half of the 1980s - the first half of the 1990s. (Some aspects of the problem)], Izvestiya Samarskogo nauchnogo tsentra Rossiiskoi akademii nauk [Bulletin of Samara Scientific Centre of the Russian Academy of Sciences], vol. 10, no. 1 (23) (2008): 204-20. (In Russian)

Kak organizovat' rotnuyu yacheiku: (Po dokladu tov. Podvoiskogo) [How to organize a company cell: (According to the report by Comrade Podvoisky)]; compiled by Evgenii Babin, $2^{\text {nd }}$ edition, Kiev: Polit. upr. Nar. kom. po voennym delam Ukrainy [Political administration of the People's Commissar on military affairs in Ukraine], 1919. 8 p. (In Russian)

Kalashnikova, E.B. Ideologicheskaya deyatel'nost' organov sovetskoi vlasti v chastyakh deistvuyushchei armii v gody Grazhdanskoi voiny v Rossii (1918-1920 gg.) [The Ideological Activity of the Soviet Authorities in the Units of the Army during the Russian Civil War (1918-1920)]. Samara: Izd-vo SNTs RAN, 2007. 112 p. (In Russian)

Kenez, P. Krasnaya ataka, beloe soprotivlenie. 1917-1918 [Red Attack, White Resistance. 1917-1918], translated from English by K.A. Nikiforov. Moscow: Tsentrpoligraf, 2007. 287 p. (In Russian)

Klochkov, V.A. Krasnaya Armiya - shkola kommunisticheskogo vospitaniya sovetskikh voinov. 1918-1941 gg [The Red Army as a School of Communist Education for Soviet Soldiers. 19181941]. Moscow: Nauka, 1979. 227 p. (In Russian)

Kolychev, V.G. Partiino-politicheskaya rabota v Krasnoi Armii v gody grazhdanskoi voiny 1918-1920 [Party-Political Work in the Red Army during the Civil War of 1918-1920]. Moscow: Nauka, 1979. 407 p. (In Russian)

Korneev, V.V. "Krizis istoricheskoi nauki v Rossii" [Crisis of Historical Science in Russia], Centaur, no 4 (1994): 87-93. (In Russian)

KPSS i voennoe stroitel'stvo [CPSU and Military Construction], edited by A. A. Epishev. Moscow: Voenizdat, 1982. 312 p. (In Russian)

Mackintosh, L.M. The political administration. The Red Army. Cambridge, MA/London: Harvard University Press, 1956. 480 p.

Matyunin, Z.N. Perebolevshie 'leviznoi'. V.I. Lenin i anglo-amerikanskie 'levye' na II kongresse Kominterna [Recover from 'leftism'. V. I. Lenin and the Anglo-American 'Left' at the $2^{\text {nd }}$ World Congress of the Comintern]. Leningrad: Lenizdat, 1990. 254 p. (In Russian)

Molodtsygin, M.A. Krasnaya Armiya: rozhdenie i stanovlenie. 1917-1920 gg [The Red Army: The birth and the Evolvement. 1917-1920]. Moscow: IRI, 1997. 234 p. (In Russian)

Partiino-politicheskaya rabota v Vooruzhennykh Silakh SSSR (1918-1973 gg.): istoricheskii ocherk [Party-political work in the Armed Forces of the USSR (1918-1973): A Historical Essay], edited by A.A. Epishev. Moscow: Voenizdat, 1974. 366 p. (In Russian)

Pipes, R. The Formation of the Soviet Union: Communism and Nationalism, 1917-1923. Cambridge: Harvard University Press, 1997. 365 p. 
Politorgany Sovetskikh Vooruzhennykh Sil: istoriko-teoreticheskii ocherk [Political Bodies of the Soviet Armed Forces: A historical and theoretical essay], edited by G. Sredin. Moscow: Voenizdat, 1984. 432 p. (In Russian)

Popova, O.N. Kul'turno-prosvetitel'naya rabota v Krasnoi Armii: 1918-1923 gg. [Cultural and educational work in the Red Army: 1918-1923]. PhD thesis. St Petersburg, 2009. 26 p. (In Russian).

Posvyatenko, O.N. Deyatel'nost' organov gosudarstvennoi vlasti i voennogo upravleniya po politicheskomu vospitaniyu voennosluzhashchikh Krasnoi Armii (1918-1924) [The activities of state bodies and military administration for the political education of the military of the Red Army (1918-1924). PhD thesis]. Moscow, 2010. 24 p. (In Russian).

Posvyatenko, O.N. Osnovnye napravleniya deyatel'nosti organov gosudarstvennoi vlasti i voennogo upravleniya po politicheskomu vospitaniyu boitsov i komandirov Krasnoi Armii v 1921$1923 \mathrm{gg}$. [The main activities of state and military authorities in the political education of fighters and commanders of the Red Army in 1921-1923], Izvestiya Samarskogo nauchnogo tsentra Rossiiskoi akademii nauk [Bulletin of Samara Scientific Centre, Russian Academy of Sciences], vol. 18, no. 6 (2016): 55-62. (In Russian)

Ryabichev, N. "Politotdel v Grazhdanskoi voine" [Political Department in the Civil War]. In Revolyutsionnaya armiya [Revolutionary Army], vol. 1 (1921): 68-73. (In Russian)

Rybnikov, V.V. Deyatel'nost' KPSS po internatsional'nomu vospitaniyu sovetskikh voinov: istoriograficheskoe issledovanie [The activities of the CPSU in the international education of Soviet soldiers: A historiographical study]. Moscow: VPA, 1986. 206 p. (In Russian)

Sakharov, A.N., O novykh podhodakh k istorii Rossii [On new approaches to the history of Russia], Voprosy istorii [Questions of history], vol. 8 (2002): 3-20. (In Russian)

Semykin, V.A. "Politorgany - organizatory agitatsionno-massovoi raboty $\mathrm{v}$ deistvuyushchei armii (1918-1920 gg.): nekotorye aspekty problemy" [Political bodies - organizers of mass campaign in the active army (1918-1920): Some aspects of the problem], Klio [Klio], vol. 9(69) (2012): 79-81. (In Russian)

Utkin, B.P. "M.V. Frunze o partiino-politicheskoi rabote v armii i na flote [M. V. Frunze on party-political work in the army and Navy], Voenno-istoricheskii zhurnal [Military History Journal], vol. 10 (1985): 52-57. (In Russian)

Vladimirtsev, V.S. Partiino-politicheskaya rabota na Yuzhnom fronte v period razgroma Denikina (oktyabr' 1919 - yanvar' 1920 gg.). Diss. ... kand. ist. nauk [Party-political Work on the Southern Front during the Period of Denikin's Defeat (October 1919 - January 1920). Thesis for a Candidate degree (PhD dissertation) in Historical Sciences]. Moscow, 1952. 334 p. (In Russian)

Voennaya pedagogika i psikhologiya [Military Pedagogy and Psychology], edited by A.V. Barabanshchikov. Moscow: Voenizdat, 1986. 240 p. (In Russian) 